\title{
E2F1 wt Allele
}

National Cancer Institute

\section{Source}

National Cancer Institute. E2F1 wt Allele. NCI Thesaurus. Code C52538.

Human E2F1 wild-type allele is located in the vicinity of 20q11.2 and is approximately 11 $\mathrm{kb}$ in length. This allele, which encodes transcription factor E2F1 protein, is involved in the modulation of the cell cycle. 